\title{
Kapasitas Sumber Daya Manusia, Pemanfaatan Teknologi Informasi dan Pengendalian Intern Terhadap Nilai Informasi Pelaporan Keuangan
}

\author{
Riang Agustin $\mathrm{S}^{1}$, Dwi Cahyono ${ }^{2}$, Gardina Aulin ${ }^{3}$ \\ 1,2,3 Program Studi Akuntansi, Fakultas Ekonomi dan Bisnis, Universitas Muhammadiyah Jember
}

\section{A R T I C L E I N F O}

Article history:

Received 01 December 2019

Received in revised form 31 December 2019

Accepted 15 January 2020

Available online 26

February 2020

\section{Kata Kunci:}

Nilai Informasi Pelaporan

Keuangan Pemerintah,

Kapasitas Sumber Daya

Manusia, Pemanfaatan

Teknologi Informasi dan

Pengendalian Intern

Keywords:

Value Of Government

Financial Reporting

Information, Human

Resource Capacity

Utilization Of Information

Technology and Internal

Control

\begin{abstract}
A B S T R A K
Penelitian ini bertujuan untuk mengetahui pengaruh kapasitas sumber daya manusia, pemanfaatan teknologi informasi dan pengendalian intern terhadap nilai informasi pelaporan keuangan pemerintah daerah Kabupaten Lumajang. Pendekatan yang digunakan dalam penelitian ini adalah kuantitatif. Responden dalam penelitian ini kepala bagian keuangan, staf akuntansi dan pihak yang terkait dalam pelaporan keuangan pada OPD pemerintah kabupaten Lumajang. Dari 66 kuisoner yang dibagikan diperoleh 64 responden yang dimasukan dalam pengolahan data. Analisis data menggunakan program SPSS versi 21. Metode statistik yang digunakan untuk menguji hipotesis linier berganda. Hasil penelitian ini menunjukan bahwa kapasitas sumber daya manusia, pemanfaatan teknologi informasi tidak berpengaruh signifikan terhadap nilai informasi pelaporan keuangan pemerintah daerah sedangkan pengendalian intern berpengaruh signifikan terhadap nilai informasi pelaporan keuangan pemerintah daerah kabupaten Lumajang.
\end{abstract}

\section{A B S T R A C T}

This study aims to determine the effect of human resource capacity, utilization of information technology and internal control on the value of financial reporting information in the Lumajang regency government. The approach used in this research is quantitative. Respondents in this study were heads of finance, accounting staf and related parties in financial reporting to the OPD government of Lumajang district. Of the 66 questionnaires distributed, 64 respondents were included in the data processing. Data analysis used SPSS version 21. The statistical method used to test multiple linear hypotheses. The results of this study indicate that the capacity of human resources, the use of information teknologi does not significantly influence the value of financial reporting information of the local goverment while internal control has a significant effect on the value of financial reporting information of the Lumajang district goverment.

\footnotetext{
* Corresponding author.

E-mail addresses: riangas31@gmail.com (Riang Agustin S)
} 


\section{Pendahuluan}

Organisasi sektor publik diidentikkan dengan pemerintahan atau badan usaha dalam mayoritas kepemilikannya di tangan pemerintah bertanggung jawab melakukan dalam pelayanan publik, memenuhi kesejahteraan dibidang kehidupan seperti kesehataan, pendidikan, keamananan perekonomian dari kebebasan dalam beragam hal lainnya. Tujuan organisasi sektor publik berbeda dengan organisasi sektor swasta. Dari ilmu ekonomi, sektor publik juga sebagai suatu entitas dalam aktivitasnya berhubungan dengan usaha untuk menghasilkan barang dan pelayanan publik.

Perkembangan akuntansi sektor publik yang semakin mengalami kemajuan menimbulkan tuntutan lebih besar terkait dengan dilakukannya transparansi dan akuntanbilitas publik oleh lembagalembaga sektor publik (Mardiasmo, 2006). Upaya konkrit dalam mewujudkan transparansi dan akuntanbilitas pengelolaan keuangan pemerintah, baik pemerintah pusat maupun pemerintah daerah yaitu dengan menyampaikan laporan pertanggungjawaban berupa laporan keuangan. Laporan keuangan pemerintah daerah bentuk laporan pertanggungjawabannya atas pengelolaan keuangan daerah selama satu tahun anggaran. Dalam bentuk pertanggungjawaban dan penyelenggaraan pemerintah telah diatur dalam undang-undang nomor 17 Tahun 2003 tentang keuangan negara dan undang-undang nomor 32 Tahun 2004 tentang pemerintah daerah, dalam mewujudkan transparansi dan akuntabilitas pengelolaan keuangan pemerintah, baik pemerintah pusat maupun pemerintah daerah dalam menyampaikan laporan pertanggungjawaban berupa laporan keuangan. Apabila laporan keuangan pemerintah tidak sesuai dengan karakteristik yang ditetapkan, akan mengakibatkan kesalahan dalam pengambilan keputusan mengenai alokasi sumber daya, nantinya berdampak pada kerugian daerah, kelemahan administrasi, kekurangan penerimaan, ketidakhematan, ketidakefisienan, dan ketidakefektifan sumber daya. Dalam standar akuntansi pemerintah (SAP) bahwa laporan keuangan harus memenuhi standar yang ditetapkan dalam pemerintah No. 71 Tahun 2010, yaitu: relevan, andal, dapat dibandingkan dan dapat dipahami.(Yuliani, Nardirsyah dan Bakar 2010).

Menurut Basnawi (2017) Sumber daya manusia merupakan salah satu unsur yang sangat berperan dalam menjamin keberlangsungan suatu organisasi. Kapasitas sumber daya manusia adalah kemampuan seseorang atau individu, suatu organisasi (kelembagaan), suatu sistem melaksanakan fungsifungsi atau kewenangannya dalam mencapai tujuan seacra efektif dan efisien. Kapasitas harus dilihat sebagai kemampuan untuk mencapai kinerja, untuk menghasilkan keluaran-keluaran (ouput) dan hasilhasil (outcomes). Menurut Yosefrinaldi (2017) Kapasitas sumber daya manusia adalah kemampuan sumber daya manusia untuk melaksanakan tugas dan tanggung jawab yang diberikan kepadanya dengan bekal pendidikan, pelatihan, dan pengalaman yang cukup memadai. Sumber daya manusia merupakan pilar penyangga utama sekaligus penggerak roda organisasi dalam usaha mewujudkan visi dan misi serta tujuan dari organisasi tersebut. Sumber daya manusia dapat diukur melalui rata-rata pendidikan, pelatihan dan tingkat pengalaman. Pendidikan yaitu suatu yang universal dalam kehidupan manusia. Pelatihan adalah proses sistematis mengubah tingkah laku seseorang untuk mencapai tujuan organisasi. Pelatihan yang baik, harus berkaitan dengan keahlian dan kemampuan untuk melaksanakan pekerjaannya. Pengalaman dilihat dari lamanya seorang bekerja, dengan pengalaman seseorang akan terbiasa melakukan suatu pekerjaan dan mempunyai wawasan yang luas, mudah beradaptsi dengan lingkungan sekitar. Warisno (2008) menjelaskan bahwa pengelolaaan keuangan daerah yang baik, Satuan Kerja Perangkat Daerah (SKPD) harus memiliki sumber daya yang kompeten, yang didukung dengan latar belakang,pendidikan akuntansi, sering mengikuti pendidikan dan pelatihan, dan mempunyai pengalaman dibidang keuangan. Hal tersebut diperlukan untuk menerapkan sistem akuntansi yang ada. Sumber daya manusia yang kompeten tersebut akan mampu memahami logika akuntansi yang bai. Kegagalan sumber daya manusia Pemerintah Daerah dalam memehami dan menerapkan logika akuntansi akan berdampak pada kekeliruan laporan keuangan yang dibuat dan ketidakpastian laporan dengan standar yang diterapkan pemerintah.

Menurut Ngafifi (2014) Kemajuan teknologi adalah sesuatu yang tidak bisa dihindari dalam kehidupan ini, karena kemajuan teknologi akan berjalan sesuai dengan kemajuan ilmu pengetahuan. Setiap inovasi diciptakan untuk memberikan manfaat positif bagi kehidupan manusia. Teknologi juga memberikan banyak kemudahan, serta sebagai cara baru dalam melakukan aktivitas manusia. Manusia juga sudah menikmati banyak manfaat yang dibawa oleh inovasi-inovasi teknologi yang telah dihasilkan dalam dekade terakhir ini. Teknologi merupakan suatu sistem informasi yang penting dalam kehidupan sehari-hari dan untuk mempermudahkan dalam menjalankan suatu pekerjaan. Teknologi informasi berperan dalam menyediakan informasi yang bermanfaat bagi para pemakai pengambil keputusan di dalam organisasi termasuk dalam hal pelaporan sehingga mendukung proses pengambilan keputusan dengan lebih efektif. Informasi yang tepat waktu merupakan bagian dari nilai informasi (ketepatan waktuan) dapat dicapai dengan peran komponen teknologi (Jogiyanto 1995:18). Menurut 
Winidyaningrum (2010) pemanfatan teknologi mencakup adanya pengolahan data, pengolahan informasi, sistem manajemen dan proses kerja secara elektronik dan pemanfaatan kemajuan teknologi informasi agar pelayanan publik dapat diakses secara mudah dan murah oleh masyarakat. Sistem akuntansi pemerintah perlu untuk memanfaatkan semua jenis informasi dan teknologi komputer untuk memberikan informasi dan layanan pemerintah kepada masyarakat.

Menurut suwardjono (2005:111) nilai informasi adalah kemampuan informasi untuk meningkatkan pengetahuan dan keyakinan pemakai dalam pengambilan keputusan. Agar informasi dapat mendukung dalam pengambilan keputusan dan dapat dipahami, maka informasi yang bermanfaat adalah informasi yang mempunyai nilai dan informasi akuntansi harus mempunyai beberapa karakteristik kualitatif yang disyaratkan. Karakteristik kualitatif laporan keuangan adalah ukuran-ukuran normatif yang perlu diwujudkan dalam informasi akuntansi sehingga dapat memenuhi tujuannya (Nordiawan,2008).

Fenomena yang terjadi terkait dengan laporan keuangan pemerintah Lumajang mendapat perhatian khusus atas prestasinya yang buruk dalam penyampaian Laporan Keuangan Pemerintah Daerah (LKPD), sehingga gagal mendapatkan opini wajar tanpa pengecualian (WTP) seperti Tahun 2017 lalu. Harapannya, di Tahun 2018 mendapatkan WTP. Dilapori oleh BPK RI bahwa Kota Lumajang bahwa atas opini auditnya WDP. Kabupaten Lumajang turun kelas yang sebelumnya WTP turun ke WDP. Gagal menerima opini WTP, lantaran penyajian LKPD-nya kurang berkualitas. LKPD itu sudah diatur dengan standart akuntansi pemerintah. Kalau penyajiannya memenuhi stnadar, tentu mendapatkan opini tertinggi yaitu WTP. Ada 7 bab yang dikerjakan, mulai dari realisasi anggaran, sisa anggaran lebih, laporan operasioanal, kas, neraca, dan laporan mutasi. Hal ini menunjukkan efektivitas SPI pemerintah daerah belum optimal. Oleh karena itu peran sistem pengendalian merupakan hal penting dalam menentukan kualitas laporan keuangan pemerintah daerah. Peran sistem pengendalian internal yaitu pemberian keyakinan atas keandalan pelaporan keuangan dengan memperoleh opini WTP dari BPK yang menjadi alat pengambilan keputusan dan melakukan pendeteksian dan penyelidikan mengenai penggelapan atau penipuan (fraud). Selain itu dalam pemerintah kabupaten Lumajang akan mengoptimalkan potensi wisata yang dimiliki untuk mendongkrak pendapatan daerah. Sebab, Lumajang memiliki tempat wisata yang indah.

\section{Metode}

Data penelitian pada dasarnya dapat dikelompokkan menjadi tiga jenis, yaitu data subjek, data fisik, dan data dokumenter. Pada penelitian ini jenis data yang digunakan yaitu jenis data subjek. Data subjek adalah jenis data yang penelitiannya berupa opini, sikap, pengalaman atau karakteristik dari seseorang atau sekelompok orang menjadi subjek penelitian atau responden (Indriantoro dan Supomo, 2007). Dalam penelitian ini berbentuk tanggapan responden yang diberikan secara tertulis. Respon pada penelitian ini diberikan dalam bentuk kuisoner. Sumber datanya termasuk dalam data primer. Merupakan sumber data penelitian yang diperoleh secara langsung dari sumber asli (Indriantoro dan Supomo, 2007). Data primer diperoleh dari hasil pengisian kuisoner oleh responden, yaitu kepala dan staf bagian keuangan atau administrasi.

\section{Hasil dan Pembahasan}

\section{A. Deskripsi Responden}

Data penelitian dikumpulkan dengan mengirimkan sebanyak 66 Kuisoner yang diantar langsung ke 22 Organisasi Perangkat Daerah Kabupaten Lumajang dengan responden 66. Pengiriman kuisoner dilakukan pada tanggal 15 juli 2019. Setelah 2 minggu kuisoner yang kembali sebanyak 64 lembar kuisoner.

Tabel 1. Rincian Pengiriman dan Pengembalian Kuisoner

\begin{tabular}{lc}
\hline \multicolumn{1}{c}{ Keterangan } & Jumlah \\
\hline Kuesioner yang dikirim & 66 Kuesioner \\
Kuesioner yang kembali & 64 Kuesioner \\
Kuesioner yang dapat digunakan & 64 Kuesioner \\
Kuesioner yang tidak kembali (66-64) & 2 Kuesioner \\
\hline
\end{tabular}


Pengiriman kuesioner dilakukan secara langsung dengan batas pengambilan 2 minggu setelah pembagian kuisoner. Kuisoner yang kembali sebanyak 64 dimana semuannya data dapat digunakan.

\section{B. Jenis Kelamin Responden}

Data responden berdasarkan karakteristik jenis kelamin dapat dilihat pada tabel dibawah ini.

Tabel 2. Karakteristik Responden Berdasarkan Jenis Kelamin

\begin{tabular}{clcc}
\hline No & Jenis Kelamin & Jumlah & Persentase \\
\hline 1 & Laki-laki & 30 & $47 \%$ \\
2 & Wanita & 34 & $53 \%$ \\
\hline & Total & $\mathbf{6 4}$ & $\mathbf{1 0 0 \%}$ \\
\hline
\end{tabular}

Berdasarkan Tabel diatas diketahui bahwa responden sebagian besar berjenis kelamin wanita sebesar 53\%. Sehingga dapat disimpulkan bahwa sebagian besar organisasi perangkat daerah di Kabupaten Lumajang adalah berjenis kelamin wanita.

\section{Umur Responden}

Data responden berdasarkan usia responden dilihat pada tabel dibawah ini

Tabel 3. Gambaram Usia Responden

\begin{tabular}{ccc}
\hline Umur & Frekuensi & Persentase \\
\hline $20-30$ & 25 & $39 \%$ \\
$30-40$ & 22 & $34 \%$ \\
$40-50$ & 17 & $27 \%$ \\
\hline Total & $\mathbf{6 4}$ & $\mathbf{1 0 0 \%}$ \\
\hline
\end{tabular}

Berdasarkan Tabel diatas diketahui bahwa sebagian besar usia responden 20-30 tahun. Hal ini diketahui dari persentasenya sebesar 39\%.

\section{Latar Belakang Pendidikan}

Data responden berdasarkan latar belakang pendidikan dapat dilihat pada tabel dibawah ini

Tabel 4. Gambaran latar belakang pendidikan responden

\begin{tabular}{lccc}
\hline & Pendidikan & Frekuensi & Persentase \\
\hline SMA & & 17 & $27 \%$ \\
Diploma & 24 & $37 \%$ \\
S1 & & 20 & $31 \%$ \\
S2 & Total & 3 & $5 \%$ \\
\hline & & $\mathbf{6 4}$ & $\mathbf{1 0 0 \%}$ \\
\hline
\end{tabular}

Berdasarkan Tabel diatas diketahui bahwa responden sebagian besar berpendidikan Diploma. Hal ini diketahui dari persentasenya sebesar 37\%.

\section{E. Lama Bekerja di Organisasi Perangkat Daerah}

Data responden berdasarkan lama bekerja pada satuan kerja perangkat daerah dapat dilihat pada tabel dibawah ini

Tabel 5. Gambaran Lama Bekerja

\begin{tabular}{|c|c|c|}
\hline Pengalaman Kerja & Frekuensi & Persentase \\
\hline$<1$ Tahun & 12 & $19 \%$ \\
\hline 1-5 Tahun & 31 & $48 \%$ \\
\hline$>5$ Tahun & 21 & $33 \%$ \\
\hline Total & 64 & $100 \%$ \\
\hline
\end{tabular}


Berdasarkan Tabel diatas diketahui bahwa responden sebagian besar dalam bekerja diorganisasi perangkat daerah yaitu 1 sampai 5 tahun. Hal ini diketahui dari persentase sebesar 48\%.

Hipotesis pertama menyatakan bahwa kapasitas sumber daya manusia tidak berpengaruh signifikan terhadap nilai pelaporan keuangan daerah. Hasil yang didapatkan dari menggunakan metode analisis regresi linear berganda, menunjukkan bahwa kapasitas sumber daya manusia terhadap nilai informasi pelaporan keuangan daerah dengan hasil t hitung 0,060. Nilai t hitung lebih dari 0,05 sehingga H1 ditolak.

Hasil penelitian ini bahwa ketidaksignifikan disebabkan kondisi kapasitas sumber daya manusia di sub bagian akutansi tata usaha keuangan yang belum mendukung. Meskipun pemerintah kabupaten Lumajang telah memperbentukan lebih kurang tujuh puluh tenaga akuntansi yang tersebar di satuan kerja perangkat daerah, namun belum optimal. Karena dengan banyaknnya volume transaksi keuangan pemerintah kabupaten Lumajang.

Temuan ini sejalan dengan penelitian Indriasari dan Nahartyo (2008). Temuan empiris dari penelitian ini menunjukkan masih minimnnya pegawai berlatar belakang pendidikan akutansi, belum jelasnnya job description, walaupun sisitem akutansi yang dibangun sudah baik tetapi sumberdaya manusianya tidak memiliki kapasitas untuk melaksanakannya, maka akan menimbulkan hambatan dalam pelaksanaan fungsi akuntansi yang ada dan akhirnnya informasi akuntansi sebagai produk dari sistem akunntansi bisa jadi kualitasnya buruk. Informasi yang dihasilkan menjadi informasi yang kurang atau tidak memiliki nilai, salah satunnya keandalan sebagaimana yang masih banyak ditemui dalam pelaporan keuangan pemerintah daerah.

Hipotesis kedua menyatakan bahwa pemanfaatan teknologi informasi tidak berpengaruhsignifikan terhadap nilai informasi pelaporan keuangan pemerintah daerah. Hasil yang didapatkan dari analisis regresi linear berganda, menunjukkan bahwa pemanfaatan teknologi informasi terhadap nilai informasi pelaporan keuangan daerah dengan hasil t hitung 0,450. Nilai t hitung lebih dari 0,05 sehingga H2 ditolak. Berdasarkan penjelasan Peraturan Pemerintah No 56 Tahun 2005 tentang sistem informasi keuangan daerah disebutkan bahwa untuk menindaklanuti terselenggarannya proses pembangunan yang sejalan dengan prinsip tata kelola pemerintah yang baik (Good Governance). Maka dari itu pemerintah daerah memiliki kewajiban untuk mengembangkan dan memanfaatkan kemajuan teknologi informasi untuk meningkatkan kemampuan mengelola keuangan daerah kepada pelayanan publik. Hasil penelitian ini sejalan dengan penelitian yang dilakukan oleh Setyowati, Isthika, Pratiwi (2016) menyatakan pemanfaatan teknologi informasi tidak mempunyai pengaruh yang signifikan. Hal ini menunjukkan bahwa pemerintah belum sepenuhnya memanfaatkan sistem informasi akuntansi keuangan daerah. Walaupun komputer yang dimiliki sudah cukup banyak dan tersambung dengan jaringan internet, akan tetapi untuk proses pengiriman informasi dan komunikasi para pegawai belum bisa memanfaatkan fasilitas secara maksimal. Pemerintah di Kabupaten Lumajang masih belum maksimal dalam memanfaatkan teknologi informasi yang ada, sehingga dalam institusinnya masih banyak juga para pegawai dan karyawan yang tidak memaksimalkan kenudahan teknologi informasi ini.

Hipotesis ketiga menyatakan bahwa pengendalian intern terhadap nilai pelaporan keuangan pemerintah daerah. Hasil yang didapatkan menggunakan metode analisis regresi liniear berganda, menunjukkan bahwa pengendalian intern dengan hasil t hitung 0,000. Nilai uji t hitung kurang dari 0,05 sehingga $\mathrm{H} 3$ telah diterima. Hasil dari yang penelitian ini menunjukkan bahwa sistem pengendalian intern pada pemerintah Kabupaten Lumajang sudah efektif dan sesuai dengan peraturan yang telah ditetapkan oleh pemerintah. Dalam penyusunan laporan keuangan sudah dilakukan dengan teliti dalam memerhatikan kebocoran atas laporan keuangan. OPD di Kabupaten Lumajang sudah menggunakan sistematika yang sesuai dengan tujuan instansi pemerintah dan tujuan pada tingkatan kegiatan secara komprehensif dengan melihat sisi resiko dari faktor eksternal dan internal. Hasil penelitian ini konsisten dengan penelitian oleh Rahmadani (2015) menyatakan bahwa variabel pengendalian internal berpengaruh positif signifikan terhadap kualitas laporan keuangan. Penelitian tersebut menyatakan semakin baiknya pengendalianinternal maka akan semakin baik juga kualitas laporan keuangan daerah yang dihasilkan

\section{Simpulan dan Saran}

Penelitian ini dilakukan untuk menganalisis dan mengetahui pengaruh Kapasitas Sumber Daya Manusia (SDM), pemanfaatan Teknologi Informasi (TI), dan Sistem Pengendalian Intern (SPI) terhadap nilai informasi pelaporan keuangan daerah di Kabupaten Lumajang. Berdasarkan hasil analisis data yang sudah dilakukan dan pembahasan yang telah diuraikan pada bab sebelumnnya, adapun kesimpulan yang diperoleh sebagai berikut: 1) Kapasitas sumber daya manusia tidak berpengaruh terhadap nilai informasi pelaporan keuangan; 2) Pemanfaatan teknologi informasi tidak berpengaruh terhadap nilai informasi 
pelaporan keuangan; 3) Sistem pengendalian intern berpengaruh signifikan terhadap nilai informasi pelaporan keuangan.

Berdasarkan keterbatasan diatas peneliti dapat memberikan beberapa saran yang dapat dipertimbangkan dan mendapat hasil yang lebih baik, yaitu sebagai berikut: 1) Mengaharapkan untuk penelitian selanjutnya dapat memilih kuesioner yang dapat dipahami oleh responden, dan saat pembagian kuesioner harap dijelaskan terlebih agar mendapatkan hasil yang lebih baik; 2) Bagi peneliti selanjutnya disarankan untuk menambahkan metode survey dengan mendatangi langsung atau melakukan wawancara terhadap responden yang menjadi sampel penelitian sehingga dapat diperoleh hasil sesuai dengan kondisi sebenarnya; 3) Peneliti selanjutnya diharapkan dapat mengembangkan penelitian dengan menambahkan variabel yang mempengaruh nilai informasi pelaporan keuangan misalnya variabel penerapan standar akuntansi.

\section{Daftar Rujukan}

Basnawi, Choiriyah. 2017. Pengembangan Kapasitas Sumber Daya Manusia Dalam Pengelolaan Keuangan Daerah Melalui Clinic Center Oleh Unit Pelaksana Teknislaboratorium Pengelolaan Keuangan Daerah (UPT-LPKD) Jawa Timur. Kebijakan dan Manajemen Publik, Volume 5, Nomor 3, Hal.1-9. Tersedia Pada: http://journal.unair.ac.id/download-fullpapers-kmp3e90c5852cfull.pdf.

Ghozali, Imam. 2011. Aplikasi Analisis Multivariat dngan Program SPSS. Semarang: Badan Penerbit-UNDIP

Ghozali, Imam. 2016. Aplikasi Analisis Multivariete Dengan Program IBM SPSS 23 (Edisi 8). Cetakan ke VIII. Semarang; Badan Penerbit Universitas di Ponegoro.

Intern Akuntansi (Studi Empiris di Pemda SUBOSUKAWONOSRATEN).

Jugiyanto, HM. 1995. Analisis dan Desain System Informasi : Pendekatan $\quad$ Terstruktur $\quad$ Teori $\quad$ Dan Praktek Aplikasi Bisnis. Andi Offies. Yogyakarta.

Keuangan Pemerintah Daerah dengan Variabel Intervening Pengendalian

Mardiasmo. 2006. Akuntansi Sektor Publik. Yogyakarta: Penerbit Andi.

Mardiasmo. 2006. Perwujudan Transparansi dan Akuntabilitas Publik: Suata Sarana Good Governance. Jurnal Akuntansi Pemerintah, Vol. 2 No.1, Hal 1-7.

Ngafifi, Muhamad. 2014. Kemajuan Teknologi Dan Pola Hidup Manusia Dalam Perspektif Sosial Budaya. Jurnal Pembangunan Pendidikan: Fondasi dan Aplikasi Volume 2, Nomor 1 Hal. 33-47. Tersedia Pada: https://journal.uny.ac.id/index.php/jppfa/article/view/2616.

Nordiawan, Dedi. 2008. Akuntansi Pemerintahan. Jakarta: Salemba Empat.

Republik Indonesia. Peraturan Pemerintah Republik Indonesia Nomor 71 Tahun 2010 tentang Standar Akuntansi Pemerintahan

Republik Indonesia. UU Nomor 17 Tahun 2003 tentang Keuangan Negara.

Republik Indonesia. 2005. Peraturan Pemerintah No.56 Tahun 2005 tentang Sistem Informasi Keuangan Daerah.

Republik Indonesia. Peraturan Pemerintah Nomor 65 Tahun 2010 tentang Sistem Informasi Keuangan Daerah.

Republik Indonesia UU Nomor 32 Tahun 2004 tentang Pemerintah Daerah.

Suwardjono. 2006. Teori Akuntansi: Perekayasaan Pelaporan Keuangan. Edisi Ketiga. Yogyakarta: BPFE. 
Teknologi Informasi Terhadap Keterandalan dan Ketepatwaktuan Pelaporan

Tesis. Surakarta: Unversitas Sebelas Maret.

Warisno. 2008. Faktor-faktor yang Mempengaruhi Kinerja Satuan Kerja Perangkat Daerah (SKPD) di Lingkungan Pemerintah Provinsi Jambi. Tesis. Medan: Sekolah Pascasarjana USU.

Winidyaningrum. 2009. Pengaruh Sumber Daya Manusia dan Pemanfaatan

Yosefrinaldi. 2017. Pengaruh Kapasitas Sumber Daya Manusia dan Pemanfaatan Teknologi Informasi Terhadap Kualitas Laporan Keuangan Pemerintah Daerah dengan Variabel Intervening Sistem Pengendalian Intern Pemerintah (Studi Empiris pada Dinas Pengelolaan Keuangan dan Aset Daerah Se-Sumatera Barat). Jurnal Akuntansi, Vol. 1 No. 1 Hal. 1-24. Tersedia Pada: http://ejournal.unp.ac.id/students/index.php/akt/article/view/66/54.

Yuliani, Safrida, Nadirsyah, dan Usman Bakar. (2010). "Pengaruh Pemahaman Akuntansi, Pemanfaatan Sistem Informasi Akuntansi Keuangan Daerah dan Peran Intern Audit Terhadap Kualitas Laporan Keuangan Pemerintah Daerah.” Jurnal Telaah \& Riset Akuntansi Vol.3 No.2 206-220. 